\title{
EFFECTS OF S. CEREVISIAE ADDITION TO ANATOLIAN WATER BUFFALO DIETS ON DRY MATTER INTAKE, MILK YIELD, MILK COMPOSITION AND SOMATIC CELL COUNT
}

\author{
Taskin Degirmencioglu ${ }^{1}$, Songül Sentürklü ${ }^{2}$, Selda Özbilgin ${ }^{1}$, Tülay Özcan ${ }^{3}$ \\ ${ }^{1}$ Department of Animal Health and Husbandry, Uludağ University Karacabey Vocational School. \\ Republic of Türkiye, \\ ${ }^{2} 18$ March Çanakkale University Biga Vocational School. \\ ${ }^{3}$ Uludag University Faculty of Agriculture, Department of Food Engineering, Bursa, Republic of Türkiye \\ taskin@uludag.edu.tr
}

\begin{abstract}
This study was carried out to determine the effect of yeast addition on dry matter intake, milk yield, milk composition and somatic cell count in Anatolian water buffalo diets. 10 buffaloes (genus: Bubalis, species: Bubalis bubalis) were randomly divided into two groups (five animals each), with 21 days of adaptation period and 7 days of the experimental period comprised the sampling period. SC-treated groups ( $\mathrm{n}=5 \mathrm{buffalo/group}$ ) received $30.0 \mathrm{~g}$ of SC per buffalo per day. Compared to the control group, the SC-treated group consumed more total dry matter $(\mathrm{P}<0.05 ; 14.27$ vs. $13.50 \mathrm{~kg} /$ day $)$ and produced more milk/day $(\mathrm{P}<0.01 ; 7.13 \mathrm{vs} .6 .22 \mathrm{~kg} /$ day $)$. Dietary yeast inclusion significantly increased alfalfa dry matter intake during a 28 -day lactation period $(\mathrm{P}<0.01 ; 10.41 \mathrm{vs} .9 .81 \mathrm{~kg} / \mathrm{day})$ compared with the control diet. Yeast application significantly reduced the somatic cell count (SCC) in milk $(\mathrm{P}<0.05$; 3.33 and $1.08 \mathrm{SCC}\left(\log _{10} / \mathrm{ml}\right)$ for control and SC-treated groups, respectively). The compositions of milk fat (58.40 and $59.00 \mathrm{~g} / \mathrm{kg}$ ), non-fat solids (120.00 and $122.80 \mathrm{~g} / \mathrm{kg}$ ), protein $(46.40$ and $46.26 . \mathrm{g} / \mathrm{kg}$ ) and lactose $(37.72$ and $38.90 \mathrm{~g} / \mathrm{kg}$ ) were similar for both groups. In conclusion it has been thought that farmers with Anatolian water buffalo can benefit from the use of yeast cultures in early lactation diets, which may improve efficiency and provide economic advantages.
\end{abstract}

Key words: yeast; Anatolian water buffalo; dry matter intake; milk composition; somatic cell count

\section{ВЛИЈАНИЕ НА ДОДАТОК ОД S. CEREVISIAE ВО ИСХРАНАТА НА АНАДОЛИСКИТЕ БИВОЛИ ВРЗ КОНСУМАЦИЈАТА НА СУВАТА МАТЕРИЈА, ПРИНОСОТ НА МЛЕКОТО, СОСТАВОТ НА МЛЕКОТО И БРОЈОТ НА СОМАТСКИТЕ КЛЕТКИ ВО МЛЕКОТО}

\begin{abstract}
Целта на овие истражувања беше да се одреди влијанието на квасочниот додаток во исхраната на анадолиските биволи врз консумацијата на сува материја, приносот на млекото, составот на млекото и бројот на соматските клетки во него. Во опитот беа опфатени десет биволи од видот Bubalis bubalis поделени по случаен избор во две групи (секој група содржеше по пет животни), кои поминаа низ период на адаптација од 21 ден и експериментален период од 7 дена. SC (S. cerevisiae) третираните групи ( $\mathrm{n}=5$ биволи/група) примаа 30,0 g SC на животно на ден. Во споредба со контролната група SC третираната група консумираше во поголема количина вкупни суви материи (p<0,01; 14,27 vs.13,50 kg/ден) и дневно произведуваше поголема количина на млеко ( $<0,01 ; 7,13$ vs.6,22 kg/ден). Внесувањето на квасците во исхраната, во споредба со контролната храна, значително ја зголеми консумацијата на суви материи од луцерка во текот на 28 дена период на лактација ( $<0,01 ; 10,41 \mathrm{vs} .9,81 \mathrm{~kg} /$ ден). Примената на квасците во исхраната значително го намали бројот на соматските клетки (SCC) во млекото ( $<20,05 ; 3,33$ и $1,08 \mathrm{SCC} \log _{10} / \mathrm{ml}$ за контролната и SC третираните групи, соодветно). Составот на млекото, односно составот на млечни масти $(58,40 \mathrm{и} 59 \mathrm{~g} / \mathrm{kg}), \mathrm{Ha}$ обезмастени суви материи $(120,00$ и $122,80 \mathrm{~g} / \mathrm{kg})$, на протеини $(46,40$ и $46,26 \mathrm{~g} / \mathrm{kg})$ и лактоза $(37,72$ и 38,90 $\mathrm{g} / \mathrm{kg}$ ) беше сличен кај двете испитувани групи. Од истражувањата беше заклучено дека фармерите можат да имаат корист од храната збогатена со квасци во исхраната на анадолиски биволи во почетокот на лактацијата бидејќ може да ја подобрат ефикасноста и да обезбеди економска добвка.
\end{abstract}

Клучни зборови: квасци; анадолиски биволи; консумација на сува материја; состав на млеко; број на соматски клетки 


\section{INTRODUCTION}

The number of water buffaloes in the world has decreased rapidly over the past three decades (Georgoudis et al., 1998). Most of world buffaloes live in Asia, Egypt, Southern and south-eastern Europe. Buffaloes have played an important role in the rural economy of developing Asian countryies from ancient times. For example the creamy part of milk fat of water buffaloes milk is popular and accompanies the famous Turkish dessert. Water buffaloes milk is preferably present at least in some percentage in Turkish sausage making industry (Soysal et al., 2005). Anatolian water buffaloes (AWB) are suitable farm animals for farmers living in a region with swamps and streams. Pastures are usually the primary source of nutrients for AWB. They are suitable dual-purpose animals for meat and milk and are often used by smaller farmers. AWB are given supplemental feed during milking. Yeast cultures create a suitable atmosphere for cellulolytic degradability and lactate usage by stimulating the development and activity of ruminal bacteria (Yoon and Stern 1995, 1996; Beharka and Nagaraja 1998; Newbold et al., 1996; Callaway and Martin 1997; Miller-Webster et al., 2002; Lila et al., 2004). Rose (1987) has suggested that yeasts remove oxygen in the rumen. Yeast cells in the rumen use available oxygen on the surface of freshly ingested feed to maintain metabolic activity. In addition, S. cerevisiae competes with other starch-utilizing bacteria for the fermentation of starch (Lynch and Martin, 2002), which leads to the prevention of lactate accumulation in the rumen (Chaucheyras et al., 1995). Chaucheyras et al. (1995) have also reported that S. cerevisiae provides growth factors, such as organic acids or vitamins. The use of yeast fermentation products in ruminants has been a common practice for the last 20 years. However, the effects of SC supplementation on dairy cow performance have been inconsistent (Moallem et al., 2009). In some reports, yeast culture increases the DMI of dairy cows (Williams et al., 1991; Erasmus et al., 1992; Wohlt et al., 1998; Dann et al., 2000; Moallem et al., 2009), whereas other studies were unable to measure the effect on intake (Kung et al. 1997, Soder and Holden 1999, and Schingoethe et al., 2004). Similarly, the effects of SC on the milk yield are variable. Yalçın et al. (2011) reported that yeast culture supplementation (50 g of the RumiSacc) significantly increased milk yield, tended to increase fat yield, protein yield and lactose yield of milk. However, other studies have reported no milk yield in re- sponse to yeast supplementation (Putnam et al., 1997; Soder and Holden 1999; Schingoethe et al., 2004). The determination of the somatic cell count (SCC) is used worldwide in dairy practice to describe the hygienic control of the milk (Urech et al., 1999; Wellnitz et al., 2009; Ma et al., 2000). Milk processors strive to reduce SCC because somatic cells cause a disagreeable taste, reduce cheese yield, and decrease the shelf life of milk. Low somatic cell count is important, and some dairy firms pay a premium price for milk with low SCC (Revilla et al., 2007). Although a large amount of scientific data has been evaluated regarding the use of yeast fermentation products, little research data are available on the evaluation of its use in AWB. The objective of this study was to determine the effect of yeast addition on milk yield and milk composition in AWB diets.

\section{MATERIALS AND METHODS}

Ten lactating buffaloes whose live body weight and milk yield were approximately accordant were selected, see (Table 1). 10 buffaloes were randomly divided into two groups (five animals each), with 21 days of adaptation period and 7 days of the experimental period comprised the sampling period

\section{Table 1}

Basic information on the examined buffaloes

\begin{tabular}{lcccc}
\hline \hline Groups & $\begin{array}{c}\text { Number } \\
\text { of buffaloes }\end{array}$ & $\begin{array}{c}\text { Live body Days in } \\
\text { weight }\end{array}$ & $\begin{array}{c}\text { Milk } \\
\text { milk }\end{array}$ & production \\
\hline $\begin{array}{l}\text { Control } \\
(0 \text { g/d SC })\end{array}$ & 5 & 560.00 & 15 & $4 . .86$ \\
$\begin{array}{l}\text { Treated } \\
(30.00 \mathrm{~g} / \mathrm{d} \mathrm{SC})\end{array}$ & 5 & 541.60 & 10 & 4.72 \\
\hline \hline
\end{tabular}

Experimental rations were as follows: control (concentrate feed mixture $(\mathrm{CFM})$ ) and treated (control ration plus $30 \mathrm{~g}$ yeast $\left(2.1 \times 10^{10} \mathrm{CFU} / \mathrm{g}\right)$ /d)). The CFM consisted of $40 \%$ barley, $27 \%$ wheat, $31 \%$ sunflower meal $1 \%$ marble powder, $0.75 \%$ salt and $0.25 \%$ vitamin + mineral mix. The chemical composition of ingredients is shown in Table 2.

The offered feeds were assessed to cover the requirements for each animal according to NRC (2001) allowances for daily cattle. The CFM for each animal was offered individually once daily at $6.30 \mathrm{am}$, while alfalfa was offered twice daily at 6:30 a.m. and 7:30 p.m., the buffalo had ad libitum access to water and pasture. 
Table 2

\section{Ingredient composition and chemical analyses of the diet offered to the buffaloes}

\begin{tabular}{lccc}
\hline \hline Ingredient composition & $\%$ & $\begin{array}{c}\text { Chemical } \\
\text { composition }\end{array}$ & $\begin{array}{c}(\mathrm{g} / \mathrm{kg}) \\
\mathrm{DM}\end{array}$ \\
\hline Barley & 40.0 & $\mathrm{DM}^{2}$ & 900.9 \\
Wheat & 27.0 & $\mathrm{OM}$ & 716.3 \\
Sunflower meal & 31.0 & $\mathrm{CP}$ & 184.6 \\
Marble powder & 1.0 & $\mathrm{CF}$ & 13.8 \\
Salt & 0.75 & $\mathrm{ADF}$ & 100.1 \\
Vitamin+mineral mix & 0.25 & $\mathrm{NDF}$ & 567.2 \\
Total & 100 & $\mathrm{CA}$ & 62.6 \\
& & Starch & 288.8 \\
& & M.E. Kcal $/ \mathrm{kg}^{3}$ & 2876.00 \\
\hline \hline
\end{tabular}

\footnotetext{
${ }^{1}$ Trace minerals and vitamins (per ton): $150 \mathrm{~g}$ of ferrous sulfate $800 \mathrm{~g}$ of manganese oxide, $200 \mathrm{~g}$ of copper sulfate, $50 \mathrm{~g}$ of zinc oxide, $8 \mathrm{~g}$ of potassium iodate, $2 \mathrm{~g}$ of sodium selenite, $6 \mathrm{~g}$ of cobalt sulfate, 8 million IU of vitamin A, 2 million IU of vitamin $\mathrm{D}_{3}$ and $5000 \mathrm{IU}$ of vitamin E.

${ }^{2} \mathrm{DM}$, dry matter; OM, organic materials; $\mathrm{CP}$, crude protein; $\mathrm{CF}$, crude oil; ADF, acid detergent-fibre; NDF, neutral detergent fibre; CA, crude ash.

${ }^{3}$ Obtained by calculation.
}

The content of dry matter, organic matters, crude protein, crude fat and ash in the diets were analyzed by the method AOAC (1990). Neutral detergent fiber (NDF) and acid detergent fibers (ADF) values were determined using methods outlined by Robertson and Van Soest (1981). The metabolizable energy was also estimated (NRC, 2001). Solids-not-fat content (SNF), fat, protein and lactose contents of milk were analyzed using a Milcosan FT - 120 device. The somatic cell values were performed using a Delaval Database Kit.

The statistical analysis was conducted with the SPSS software package program (1998). The covariance test was used to test differences between the initial and final milk yield, live body weight and the number of lactating buffalos in the groups. Using these parameters, no significant effects were detected between both groups. Therefore, the covariance analysis was not conducted for these traits. However, t- test was used to evaluate differences for these traits.

\section{RESULTS}

Ingredient composition and chemical analyses of the diet are shown in Table 2. The effects of SC addition on DM intake and body weight are presented in Table 3.

Table 3

Effects of Sc on the body weight, DM intake, milk yield, milk composition and somatic cell counts

\begin{tabular}{|c|c|c|c|c|c|c|c|}
\hline & \multicolumn{2}{|c|}{ Before experiment } & \multirow[t]{2}{*}{ S.E. } & \multirow{2}{*}{$\begin{array}{l}\text { Control } \\
(0 \mathrm{~g} / \mathrm{d})\end{array}$} & \multirow{2}{*}{$\begin{array}{c}\text { Treated } \\
(30.00 \mathrm{~g} / \mathrm{d})\end{array}$} & \multirow[t]{2}{*}{ S.E. } & \multirow[t]{2}{*}{ Significance } \\
\hline & Control & Treated & & & & & \\
\hline Body weight (kg) & 560.00 & 541.60 & 11.56 & 530.00 & 534.00 & 11.914 & NS \\
\hline Concentrate DM I (kg/day) & \multicolumn{2}{|c|}{2.452 .30} & 0.204 & 3.68 & 3.86 & 0.126 & NS \\
\hline Alfalfa hay DM I (kg/day) & \multicolumn{2}{|c|}{9.959 .84} & 0.191 & 9.81 & 10.41 & 0.103 & $*$ \\
\hline Total DM intake (kg/day) & \multicolumn{2}{|c|}{12.4012 .14} & 0.246 & 13.50 & 14.27 & 0.183 & $*$ \\
\hline Milk yield (kg/day) & 4.86 & 4.72 & 0.201 & 6.22 & 7.13 & 0.097 & $* *$ \\
\hline $4 \%$ fat-corrected milk ( $\mathrm{kg} /$ day $)$ & 7.12 & 6.85 & 0.56 & 7.94 & 9.90 & 0.466 & $*$ \\
\hline Milk SNF (g/kg) & 150.80 & 151.60 & 0.95 & 120.00 & 122.80 & 1.778 & NS \\
\hline Milk fat $(\mathrm{g} / \mathrm{kg})$ & 68.00 & 69.00 & 0.63 & 58.40 & 59.00 & 2.534 & NS \\
\hline Milk protein $(\mathrm{g} / \mathrm{kg})$ & 53.02 & 53.26 & 0.80 & 46.40 & 46.26 & 0.604 & NS \\
\hline Milk lactose ( $\mathrm{g} \mathrm{kg}$ ) & 41.64 & 41.52 & 0.59 & 37.72 & 38.90 & 0.9434 & NS \\
\hline Somatic cell count $\left(\log _{10} / \mathrm{ml}\right)$ & 2.80 & 3.06 & 5.16 & 3.33 & 1.080 & 4.914 & $*$ \\
\hline
\end{tabular}

NS, not significant; "P-value $<0.05$. ${ }^{* *} \mathrm{P}$-value $<0.01$ 
After SC supplementation, dry matter alfalfa consumption displayed an increasing trend of 5.76 $\%(\mathrm{P}<0.05)$ in the $\mathrm{SC}$-treated group compared to the control group. After adding $\mathrm{SC}$ in this experiment, the total DM consumption capacity was significantly higher than that in the control group $(\mathrm{P}<0.05)$, which increased by $5.39 \%$. SC-treated and control milk yields are presented in Table 3. Daily milk yields for the yeast and non-yeast groups were 4.72 and $4.86 \mathrm{~kg} /$ day, respectively, at the beginning of the study (initial period) $(\mathrm{P}>0.05)$. After adding $\mathrm{SC}$ in this experiment, the fat content of the milk yield significantly increased by $19.8 \%$ compared to that in the control group $(\mathrm{P}<0.05)$ The results for milk-fat, non-fat milk solids, and milk protein content are similar between the treatment groups (Table 3).

\section{DISCUSSION}

In this study, alfalfa DM consumption in the SC-treated group was higher than that in the control group $(5.76 \%(\mathrm{P}<0.05)$; Table 3$)$, which was consistent with the findings given by Erasmus et al. (1992) that showed an increased DM consumption with the addition of yeast $(1.4 \mathrm{~kg} / \mathrm{day})$. Compared to a non-yeast control group, Wohlt et al. (1998) also observed a 5.04\% increase in DM consumption when yeast was added to the lactation concentrate during the $4^{\text {th }}-18^{\text {th }}$ weeks of lactation $(\mathrm{P}<0.05)$. Moallem et al. (2009) documented a 0.6 $\mathrm{kg}$ /day increase in daily DM consumption following dietary yeast inclusion. The observed increase in alfalfa DM consumption correlates with the increase in $\mathrm{pH}$ and cellulolytic activity due to the stabilization of the ruminal environment by yeast application (Miller-Webster et al., 2002) Other workers have documented increased bacterial development and activity following yeast addition (Yoon and Stern, 1995, 1996; Beharka and Nagaraja, 1998; Newbold et al., 1996; Callaway and Martin 1997 and Lila et al., 2004). Previous studies have documented similar increases in DM intake following yeast addition (Williams et al., 1991; Erasmus et al., 1992; Wohlt et al., 1998; Dann et al. 2000; Lynch et al., 2002 and Moallem et al., 2009). However, other studies have not observed any effects of yeast supplementation on DM intake (Kung et al., 1997; Soder and Holden 1999; Schingoethe et al., 2004). Schingoethe et al. (2004) have evaluated the effects of supplementing dairy cow diets with yeast and have shown that DM consumption is significantly lower during the summer
$(\mathrm{P}<0.05)$. The observed response variance may be related to several factors, such as forage type, forage-to-concentrate ratio, feeding strategy, animal differences, the lactation length tested, the amount of yeast culture added, the source of the yeast culture product and seasonal effects (Williams et al., 1991; Piva et al., 1993 Kung et al., 1997 and Lesmeister et al., 2004).

As shown in Table 3, Anatolian water buffaloes that were fed yeast cultures during a 28-day lactation period produced more milk $(\mathrm{P}<0.01)$ and more $4.0 \%$ FCM than unsupplemented buffalo cows during the early lactation period $(\mathrm{P}<0.01$; 7.13 vs. $6.22 \mathrm{~kg} /$ day). Significant increases in milk production associated with yeast supplementation, have previously been reported in dairy cows (Piva et al., 1993; Wohlt et al., 1998; Kung et al. 1997; Wohlt et al. 1998; Moallem et al. 2009; Yalçın et al. (2011). Milk response to feeding yeast culture usually ranges between 1 and $2 \mathrm{~kg} / \mathrm{d}$ (Robinson and Garrett, 1999). Kellems et al. (1990) reported that microbial additives such as yeast cultures had the greatest positive effect on cows in early lactation, increasing milk yield over that of control cows. Williams et al. (1991) found that yeast cultures had the greatest effect when diets contained $60 \%$ concentrate and $40 \%$ forage. Therefore, yeast cultures fed to Anatolian water buffaloes and conventional Holstein-Friesian cows have been shown to modify rumen dynamics in a manner that stimulates the diet DM intake resulting in enhanced milk production and efficiency.

Many investigations have shown positive responses to yeast culture supplementation. However, studies have reported inconsistent results regarding the influences of yeast culture supplementation, partially due to confounding effects of ration composition, the level of yeast culture inclusion, and the source of yeast culture product (Putnam et al., 1997; Soder and Holden 1999; Schingoethe et al., 2004 Lesmeister et al., 2004). Ramírez et al. (2007) have reported that the addition of yeast does not significantly increase the yield in water buffalo but induces a difference of $0.57 \mathrm{~kg}$ milk/animal/day between the treated and untreated groups. This effect may be attributed to using water buffaloes with 84 days of lactation (late period).

The addition of dietary yeast culture to AWB lactation diets in the present study did not improve milk fat or milk protein components. Campanile et al. (2008) concluded that Saccharomyces cerevisiae supplementation increased organic matter 
digestibility thus allowing a higher energy availability for milk yield and reduced fat mobilization in buffalo cows. Desnoyers et al. (2009) reported that yeast products increased milk yield and tended to increase milk fat content but milk protein content was unaffected by treatment. Although milk fat and milk protein improvements are common effects following the administration of yeast cultures (Besong et al., 1996; Wohlt et al., 1998; Piva et al. 1993), some studies have not documented an improvement in milk components (Schingoethe et al., 2004 and Moallem et al., 2009).

In the current study, somatic cell count measurements in AWB were significantly reduced due to the yeast culture supplementation $(\mathrm{P}<0.05)$. The SCC percent was 1.08 and $3.33 \log _{10} / \mathrm{ml}$ for the yeast-treated and control groups, respectively. This result is similar to that of Zongyun et al. (2007) showing that after adding SC to the daily ration, cows somatic cell counts decreased significantly $(\mathrm{P}<0.01)$. But the precise modes of action involved are not yet clear and need further investigation.

\section{CONCLUSION}

Based on these results, farmers with Anatolian water buffaloes can benefit from the use of yeast cultures in early lactation diets, which may improve efficiency and provide economic advantages. Further investigation is required to elucidate the effects of yeast on water buffalo performance.

\section{REFERENCES}

[1] AOAC. (1990): Official methods of analysis. 15th ed. Assoc. Off. Anal Chem., Arlington, VA.

[2] Besong S., Jackson, J. A., Hicks, C. I., Hemken, R. W. (1996): Effects of a supplemental liquid yeast product on feed intake, ruminal profiles, and yield, compasition, and organoleptic characteristics of milk from lactating holstein cows. J Dairy Sci, 79: 1654-1658.

[3] Beharka A. A., Nagaraja, T. G. (1998): Effects of Aspergillus oryzae extract alone or in combination with antimicrobial compounds on ruminal bacteria. J Dairy Sci. 81: 1591-1598.

[4] Callaway E. S., Martin, S. A. (1997): Effects of Saccharomyces cerevisiae culture on ruminal bacteria that utilize lactate and digest cellulose. J Dairy Sci, 80: 20352044.

[5] Campanile G., Zicarelli, F., Vecchio, D., Pacelli, C., Neglia, G., Balestrieri, A., Di Palo, R., Infascelli, F. (2008): Effects of Saccharomyces cerevisiae on in vivo organic matter digestibility and milk yield in buffalo cows. Livest Sci, 114: 358-361.
[6] Chaucheyras F., Fonty, G., Bertin, G. J., Salmon, M., Gouet, P. (1995): Effects of a strain of Saccharomyces cerevisiae (Levucell SC), a microbial additive for ruminants, on lactate metabolism in vitro. Can J Microbiol, 42: 927-933.

[7] Dann H. M., Prockley, J. R., Mc Coy G. C., Hutjens, M. F., Garrett, J. E. (2000): Effects of yeast cultures ( $\mathrm{Sac}$ charomyces cerevisiae) on prepartum intake and postpartum intake and milk production of Jersey cows. J Dairy Sci, 83: 123-127.

[8] Desnoyers M., Giger-Reverdin, S., Bertin, G., DuvauxPonter, C., Sauvant, D. (2009): Meta-analysis of the influence of Saccharomyces cerevisiae supplementation on ruminal parameters and milk production of ruminants. $J$ Dairy Sci, 92: 1620-1632.

[9] Erasmus L. J., Botha, P. M., Kistner, A. (1992): Effect of yeast culture supplement on production, rumen fermentation, and duodenal nitrogen flow in dairy cows. $J$ Dairy Sci, 75: 3056-3065.

[10] Georgoudis A. G., Papanastasis, V. P., Boyazoğlu, J. G. (1998): Use of Water Buffalo for Environmental Conservation of Waterland. Review. Symposium VIII. Entitled "Role of Water Buffaloes in Producing Foods" of the $8^{\text {th }}$ World Conference on June 30, 1998 at Seoul National University, Seoul, Korea.

[11] Kellems R. O,, Lagerstedt, A., Wallentine, M. V. (1990): Effect of feeding Aspergillus oryzae fermentation extract or Aspergillus oryzae plus yeast culture plus mineral and vitamin supplement on performance of Holstein cows during a complete lactation. J Dairy Sci, 73: 2922-2928.

[12] Kung L. J., Kreck, E. M., Tung, R. S. (1997): Effects of a live yeast culture and enzymes on in vitro ruminal fermentation and milk production of dairy cows. J Dairy Sci, 80: 2045-2051.

[13] Lesmeister K. E., Heinrichs, A. J., Gabler, M. T. (2004): Effects of Supplemental Yeast (Saccharomyces cerevisiae) Culture on Rumen Development, Growth Characteristics, and Blood Parameters in Neonatal Dairy Calves, J Dairy Sci, 87: 1832-1839.

[14] Lila Z., Mohammed, N., Yasui, T., Kurokawa, Y., Kanda, S., Itabashi, H. (2004): Effects of a twin strain of Saccharomyces cerevisiae live cells on mixed ruminal microorganism fermentation in vitro. J Anim Sci, 82: $1847-$ 1854.

[15] Lynch H. A., Martin, S. A. (2002): Effects of Saccharomyces cerevisiae culture and Saccharomyces cerevisiae live cells on in vitro mixed ruminal microorganism fermentation. J Dairy Sci, 85: 2603-2608.

[16] Ma Y. Ryan, Barbano, C., Galton, D. M., Rudan, M. A., Boor, K. J. (2000): Effects of somatic cell count on Quality and shell-life of pasteurized fluid milk. J Dairy Sci, 83: 264-274.

[17] Miller-Webster T., Hoover, W. H., Holt, M., Nocek, J. E. (2002): Influence of Yeast Culture on Ruminal Microbial Metabolism in Continuous Culture J Dairy Sci, 85: 2009 2014.

[18] Moallem U. H., Lehrer, L., Livshitz, M., Zachut Yakoby, S. (2009): The effects of live yeast supplementation to dairy cows during the hot season on production, feed efficiency, and digestibility. J Dairy Sci, 92: 343-351. 
[19] Newbold C. J., Wallace, R. J., McIntosh, F. M. (1996): Mode of action of the yeast Saccharomyces cerevisiae as a feed additive for ruminants. Brit J Nutr, 76: 249-261.

[20] NRC (2001): Nutrient requirements of dairy cattle. National academy press, Washington. D.C. 341-353.

[21] Piva G., Belladonna, S., Fusconi, G., Sichaldi, F. (1993): Effects of yeast on dairy cow performance, ruminal fermentation, blood components, and milk manufacturing properties. J Dairy Sci, 76: 2717-2722.

[22] Putnam D. E., Schwab, C. G., Socha, M. T., Whitestone, N. L., Kierstead, N. A., Gaithwaite, B. D. (1997): Effect of yeast culture in the diets of early lactation dairy cows on ruminal fermentation and passage of nitrogen fractions and amino acids to the small intestine. $J$ Dairy Sci, 80 (2),374-384

[23] Ramírez J. F., Medina, S., Garcíaand, N.. Cifuentes, T. (2007): Effects of the supplementation with yeast Saccharomyces cerevisiae) on milk yield, and milk components of water buffalo cows from northeast of Colombia. Ital J. Anim. Sci., Vol. 6, (Suppl. 2), 502-503.

[24] Revilla I., Rodriquez-Nogales, J. M., Quintana, A. (2007): Proteolysis and texture of herd ewes milk cheese during ripening as affected by somatic cell counts. Journal of Dairy Research, 74 (2): 127-136.

[25] Rose A. H. (1987): Responses to the chemical environment. In: The Yeasts (Ed. A. H. Rose and J. S. Harrisson) Vol. 2, Academic Press, London pp: 5-40.

[26] Robertson J. B., Vansoest, P. J. (1981): The detergent System of Analysis and its Application to Human Foods. In: The Analysis of Dietary fiber in food. W.P.T. James and O. Theander, Ed. Marcel Dekker, New York, NY. pp 123.

[27] Robinson P. H., Garrett, J. E. (1999): Effect of yeast culture (Saccharomyces cerevisiae) on adaptation of cows to postpartum diets and on lactational performance. J Anim Sci, 77: 988-999.

[28] SPSS (1998): SPSS/PC+V.2.0. Base manual for the IBM $\mathrm{PC} / \mathrm{XT} / \mathrm{AT}$ and PS/2. Marjia and Morusis, SPSS Inc. 444 N. Michigan Avenue, Chicago, IL, 60611.

[29] Soysal M. İ,, Özkan, E. K. S., Tuna, Y. T., Gürcan, E. K. (2005): Genetic Characterization of Indigenous Anatolian
Water Buffalo Breed Using Microsatellite DNA Markers. Journal of Tekirdag Agricultural Faculty, 2 (3): 240-244.

[30] Soder K. J., Holden, L. A. (1999): Dry matter intake and milk yield and composition of cows fed yeast prepartum and postpartum. J Dairy Sci, 82: 605-610.

[31] Schingoethe D. J., Linke, K. N., Kalscheur, K. F., Hippen, A. R., Rennich, D. R., Yoon, I. (2004): Feed efficiency of mid-lactation dairy cows fed yeast culture during summer. J Dairy Sci, 87: 4178-4181.

[32] Urech E., Puhan, Z., Schallibaum, M. (1999): Changes in milk protein fraction as affected by subclinical mastitis. $J$ Dairy Sci, 82: 2402-2411.

[33] Yalçın S., Yalçın, S., Pınar, C., Arif, O. G., Cemalettin, B., Önder, E. (2011): The Nutritive Value of Live Yeast Culture (Saccharomyces cerevisiae) and Its Effect on Milk Yield, Milk Composition and Some Blood Parameters of Dairy Cows. Asian-Aust. J Anim Sci, 24 (10): $1377-1385$.

[34] Yoon L. K., Stern, M. D. (1995): Influence of dierct-fed microbials on ruminal microbial fermentation and performance of ruminants: A reviev. Ausstral. Asian J Anim Sci, 8: 533-555.

[35] Yoon L. K., Stern, M. D. (1996): Effects of Saccharomyces cerevisiae and Aspergillus oryzae cultures on ruminal fermentation in dairy cows. J Dairy Sci, 79: 411-417.

[36] Wellnitz O., Doherr, M. G., Woloszyn, M., Bruckmaier, R. M. (2009): Prediction of total quarter milk somatic cell counts based on foremilk sampling. J Dairy Res, 79 (3): 326-330.

[37] Wohlt, J. E., Corcione, T. T., Zajac, P. K. (1998): Effect of yeast on feed intake and performance of cows fed diets based on corn silage during early lactation. J Dairy Sci, 81: 1345-1352.

[38] Williams, P. E. V., Tait, C. A. G., Innesand, G. M., Newbold, C. J. (1991): Effects of the inclusion of yeast culture (Saccharomyces cerevisiae plus growth medium) in the diet of dairy cows on milk yield and forage degradation and fermentation patterns in the Rumen of steers, J. Anim. Sci. 69: 3016-3025.

[39] Zong-yun X. U., Zhangand, L. J., Han, J. W. (2007): Effects of Se-Yeast in dairy ration on somatic cell and anti-oxidation performance. Chinese J Anim Nutr, 19 (6). 